\title{
LUCA PACIOLI: UM MESTRE DO RENASCIMENTO
}

\section{LUCA PACIOLI: A MASTER OF THE RENAISSANCE}

\section{LUCA PACIOLI: UN MAESTRO DEL RENACIMIENTO}

\section{(ANTÔNIO LOPES DE SÁ)}

\author{
IVAM RICARDO PELEIAS \\ Doutor, Mestre e Bacharel em Ciências Contábeis \\ Professor e Pesquisador Contábil do Centro Universitário Fecap e da Pontifícia \\ Universidade Católica de São Paulo - PUC-SP - Docente da disciplina História do \\ Pensamento Contábil \\ ivamrp@fecap.br/ivamrp@contadoresforenses.net.br
}

A obra, primeira em língua portuguesa publicada no Brasil, foi lançada na forma impressa em 2003 e a $2^{a}$ edição, revista e ampliada em meio digital, em 2004. É uma tradução comentada do Tratado de Contas e Escrituras (Tractatus de Computis et Scripturis), escrito por Luca Pacioli, intitulado Pai da Contabilidade Moderna e descrito por Weis e Tinius (1991) como "O herói desconhecido da Renascença". As duas edições, consultadas para a elaboração desta resenha, possuem apresentações específicas, destacando a importância e a utilidade do processo de registro contábil, complementadas com as credenciais do autor, o já saudoso Professor Doutor Antônio Lopes de Sá. A publicação está dividida em seis capítulos, cada qual a seguir resenhado, com base na $2^{a}$ edição.

O Capítulo I (O ambiente histórico da era das partidas dobradas) apresenta ao leitor o cenário do surgimento, do desenvolvimento e da consolidação das partidas dobradas na Itália, retratando o período em que viveu Luca Paciolii (ou Paciolo, ao tratá-lo pelo sobrenome); descreve, ainda, as mudanças culturais, políticas, sociais e econômicas da época, oferecendo ao leitor uma noção ampla das ocorrências sobre o Renascimento, uma época culturalmente fecunda. O Capítulo evidencia a região italiana da Toscana como berço da partida dobrada, entre os anos de 1250 e 1280, e relata a descrição e posterior afirmação dos procedimentos de registro contábil que viriam a oferecer as bases para as doutrinas contábeis. 
O Capítulo II (As origens da evolução das partidas dobradas), por sua vez, cuida do surgimento e da evolução do processo de registro por partidas dobradas (também denominado processo de registro de Veneza) na Itália. Sá destaca as dúvidas ainda existentes sobre a verdadeira origem deste processo de duplo registro e apresenta os elementos comprobatórios de seu surgimento disponíveis até o momento. Segundo o que é relatado no Capítulo, Paciolo não foi o criador das partidas dobradas, mas alguém possuidor de conhecimento prático sobre elas e que buscou descrevê-las de forma didática e sistematizada.

"A literatura contábil das partidas dobradas", que é o tema do Capítulo III, traz a difusão do processo de registro contábil por partidas dobradas em período anterior à edição da Summa de Paciolo. Lá, estão descritos o surgimento, o uso e a difusão de livros de origem oriental e manuais práticos de ensino manuscritos. No Capítulo, são mencionados o "Liber Abaci" (obra que introduz o uso dos números arábicos na escrita, facilitando o registro e provavelmente contribuindo para o surgimento da partida dobrada), escrito por Leonardo Fibonacci (também chamado de "O Pisano"), em 1202, e a obra intitulada "Risale-i-Felekiye", produzida por Mazenderani em 1363. Comenta-se também sobre a possível existência de manuscritos usados para o ensino das partidas dobradas, os quais não teriam chegado aos dias atuais.

Neste capítulo, Sá apresenta o título completo da obra de Paciolo: Summa de Arithmetica Geometria Proportione et Proporcionalitá (Súmula de Aritmética, Geometria, Proporções e Proporcionalidade), na qual, na Distinctio IX (Distinção IX), se insere o Tratado XI: Tractatus de Computis et Scripturis (Tratado de Contas e Escrituras). A Summa foi originalmente impressa em dois volumes: o primeiro, com 448 páginas de texto mais 16 de introdução e o segundo, com 151 páginas de texto. No total, os dois volumes perfazem 615 páginas (SANGSTER, 2007). Para Sá, a Summa teria 616 páginas. Sangster (2007) relata publicação original do “Tratado" em 27 páginas. Sá $(2003,2004)$ e Sansgter (2007) mencionam a publicação de duas edições da Summa pela casa Editorial Paganino dei Paganini de Veneza, em 1494 e 1523. Sá lembra a publicação posterior do "Tratado" em outros países da Europa ao longo do século XV, o que, de forma combinada com a impressão por tipos móveis, ajudou a difundir a prática contábil por partidas dobradas pela Europa. Sangster (2007) informa a tradução e a publicação do "Tratado", nos últimos 150 anos, nos idiomas Inglês, Chinês, Tcheco, Alemão, Holandês, Francês, Alemão, Italiano (moderno), Japonês, Polonês, Português (não menciona se seria a obra em comento), Romeno, Russo, Espanhol e Turco.

No Capítulo IV (Luca Pacioli - gênio do Renascimento), Sá faz uma breve descrição da vida de Paciolo, informando uma existência movimentada, por conta de suas atividades, obras e da amizade com Leonardo da Vinci. Inicia informando seu nascimento na localidade de Borgo di San Sepolcro, província da cidade de Arezzo, região da Tosca- 
na, na Itália, por volta de 1445. Descreve suas atividades em Veneza, em Roma e que, provavelmente, recebeu os votos sagrados em sua terra natal em 1471, com o ingresso na Ordem Religiosa dos Franciscanos. Na sequência, relata as atividades docentes por ele exercidas, pormenores da amizade com Vinci e as influências mútuas nas obras de ambos. Segundo as fontes ali descritas, a morte da Paciolo ocorreu em 1517 e seu sepultamento deu-se na Igreja de San Giovanni D'Afra, em sua cidade natal.

O Capítulo V (A "Summa" de Paciolo e o "Tractatus") é o mais longo de todos, no qual são apresentados os 37 parágrafos (capítulos, para Paciolo) do "Tratado". Sá alerta que o texto original é prolixo, repetitivo e de difícil entendimento, por seguir os critérios da época e, por essa razão, baseou-se no trabalho de Melis (1950). Isso o motivou a buscar uma redação mais próxima possível da construção vernacular atual. Sá chama a atenção para o fato de um tratado de Contabilidade, em um livro como a Summa, parecer inadequado ou impertinente. Entretanto, ressalta que a Escrituração Mercantil era lecionada nas escolas Ábaco ou Aritmética, que cuidavam das práticas em uso no comércio, as quais, segundo Melis (1950), seriam as precursoras das Escolas ou Aulas de Comércio. Ampara-se em outras obras (MELIS, VLAEMMINCK), para relatar que o "Tratado" rompe a tradição oral do conhecimento contábil para dar-lhe um sentido literário.

Ao ler a tradução dos 37 parágrafos, o leitor identificará a estrutura e a sistematização do processo de registro contábil na forma atualmente praticada, abrangendo: o inventário inicial; as três recomendações essenciais aos bons comerciantes: dinheiro em espécie, habilidade contábil e de cálculo e organização; o respeito à cronologia para os registros; os livros necessários: diário, borrador e razão; a autenticidade e os requisitos necessários à fé pública dos livros; as formas de registro e porque debitar e creditar as operações; e os procedimentos de transporte de valores, apuração de resultados e encerramento de exercícios, entre outros. Ao longo do texto, é possível identificar trechos associados aos princípios contábeis na forma como hoje os conhecemos.

Por fim, no Capítulo VI (Comentários sobre o Tratado de Luca Pacioli”), Sá interpreta o que traduziu no Capítulo V. Declara seu desejo de esclarecer ainda mais o que, guardadas as proporções quanto às condições por ele já descritas, estaria claro no original, mas que poderia ser ofuscado pela forma de expor usada à época da edição da Summa. Para ele, a obra foi escrita para destacar a figura do comerciante, o que permite inferir o caráter prático originalmente pretendido. $\mathrm{O}$ autor encerra o Capítulo realçando no "Tratado" o valor dos controles internos sobre o patrimônio; a abrangência necessária ao processo de registro contábil (considerando ativo, passivo e patrimônio líquido); o esforço para que nada seja omitido. Finaliza realçando uma característica distintiva da obra: ter sido dedicada ao pequeno empresário, embora na época já existissem grandes organizações. 


\section{REFERÊNCIAS}

MELIS, Federigo. Storia della ragioneria. Bologna: Zuffi, 1950.

SÁ, A. L. Luca Pacioli: um mestre do renascimento. Duque de Caxias, RJ: Unigranrio, 2003. . Luca Pacioli: um mestre do renascimento. $2^{\mathrm{a}}$ edição revista e amapliada. Brasília: Fundação Brasileira de Contabilidade, 2004. Disponível em < http://www.fbc.org.br/pdf/ lucapacioli.pdf>. Acesso em 28.jun.2010.

SANGSTER, A. The printing of Pacioli's Summa in 1494: how many copies were printed? Accounting Historians Journal, vol. 34, n. 1, june 2007, pp. 125-145.

WIES, W. L., TINIUS, D. E. Luca Pacioli: Accounting's Renaissance Man. Management Accounting, vol. 73, n. 1, july 1991, pp. 54-56.

VLAEMMNINCK, J. H. Historia y Doctrinas de La Contabilidad, versão espanhola de José Maria Gonzalez Ferrando, edição EJES, Madrid, España, 1961. 